
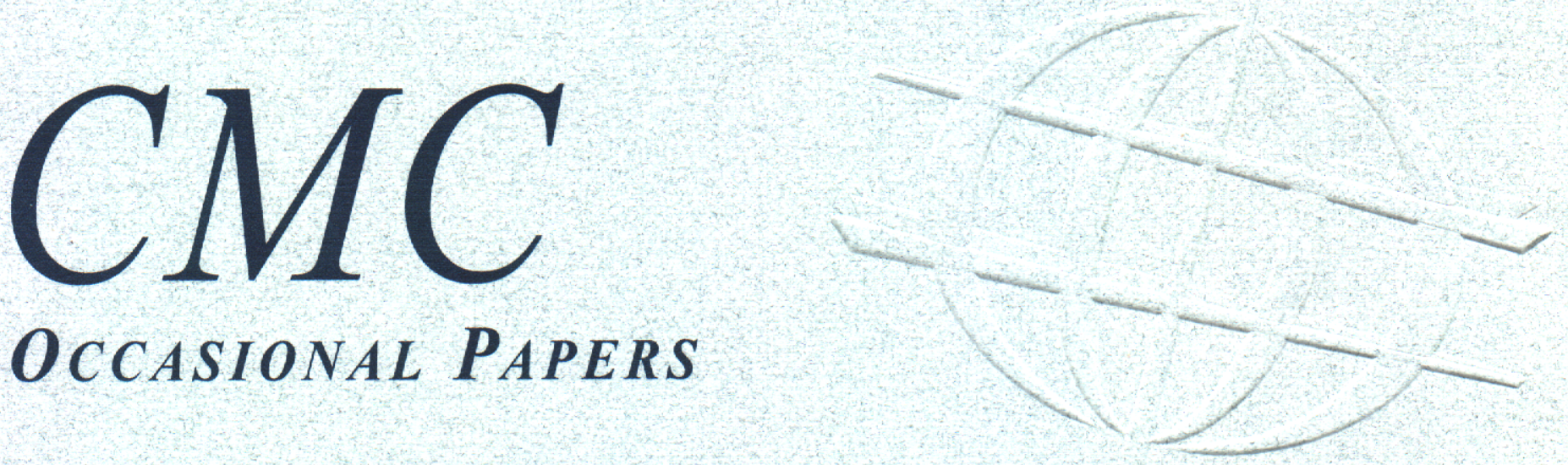

\title{
Maritime Confidence Building Measures Across the Taiwan Strait: Technical Collaboration for Human Security at Sea
}

Chyungly Lee, Ph.D

Visiting Research Scholar

Taipei, Taiwan 


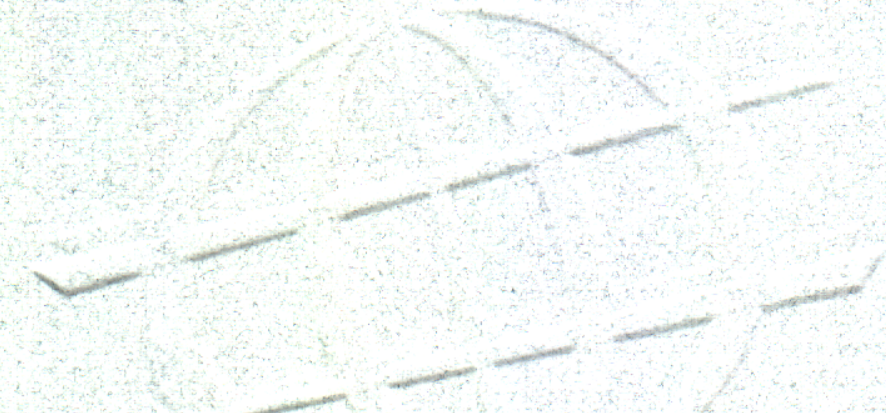

Issued by Sandia National Laboratories, operated for the United States Department of Energy by Sandia Corporation.

This report was prepared as an account of work sponsored by an agency of the United States Government. Neither the United States Government nor any agency thereof, nor any of their employees, nor any of their contractors, subcontractors, or their employees, makes any warranty, express or implied, or assumes any legal liability or responsibility for the accuracy, completeness, or usefulness of any information, apparatus, product, or process disclosed, or represents that its use would not infringe privately owned rights. Reference herein to any specific commercial product, process, or service by trade name, trademark, manufacturer, or otherwise, does not necessarily constitute or imply its endorsement, recommendation, or favoring by the United States Government, any agency thereof, or any of their contractors or subcontractors.

The views and opinions expressed herein do not necessarily state or reflect those of the United States Government, any agency thereof, or any of their contractors.

Printed in the United States of America. This report has been reproduced directly from the best available copy.

Available to DOE and DOE contractors from

U.S. Department of Energy

Office of Scientific and Technical Information

P.O. Box 62

Oak Ridge, TN 37831

Telephone:

(865) $576-8401$

Facsimile:

(865) 576-5728

E-Mail:

reports@Adonis.osti.gov

Online ordering:

http://www.doe.gov/bridge

Available to the public from

U.S. Department of Commerce

National Technical Information Service

5285 Port Royal Rd.

Springfield, VA 22161

Telephone:

(800) 553-6847

Facsimile:

(703) 605-6900

E-Mail:

Online order: orders@ntis.fedworld.gov

http://www.ntis.gov/help/ordermethods.asp?loc $=7-4 \#$ online 
SAND 2003-0753

March 2003

\section{Maritime Confidence Building Measures Across the Taiwan Strait: Technical Collaboration for Human Security at Sea}

Chyungly Lee, Ph.D.

Taipei, Taiwan

Cooperative Monitoring Center Occasional Paper/26

\section{E1] Sandia National Laboratories}

Sandia is a multiprogram laboratory operated by Sandia Corporation, a Lockheed Martin Company, for the United States Department of Energy under contract DE-AC04-94AL85000. 
The Cooperative Monitoring Center (CMC) at Sandia National Laboratories assists political and technical experts from around the world to acquire the technology-based tools they need to assess, design, analyze, and implement nonproliferation, arms control, and other cooperative security measures. As part of its mission, the CMC sponsors research on cooperative security and the role of technology. Reports of that work are provided through the Occasional Papers series. Research is conducted by Sandia staff, international technical experts, and visiting scholars. (The CMC's Visiting Scholars Program is administered by the Institute for Public Policy at the University of New Mexico.) For additional information on the CMC's programs, visit the CMC home page on the World Wide Web at $<$ http://www.cmc.sandia.gov> or write to:

Cooperative Monitoring Center

Sandia National Laboratories

Mail Stop 1373

Albuquerque, NM 87185-1373

For specific information on this report contact:

John Olsen at the above address.

This report was prepared by Sandia National Laboratories

Albuquerque, NM 87185 and Livermore, CA 94550 


\title{
Maritime Confidence Building Measures Across the Taiwan Strait: Technical Collaboration for Human Security at Sea
}

\begin{abstract}
The concept of confidence building measures (CBMs) has been developed for decades to reduce military tensions and political uncertainties in the flash points of regional security concerns. Nevertheless, the perceptions of state-centered and military-based requirements for CBMs have hampered both Beijing and Taipei from taking proactive initiatives across the Taiwan Strait in the past. Increasing economic interdependence and social interactions since the 1990 s have led both sides to establish joint efforts for ensuring peace for the prosperity and welfare of people across the Taiwan Strait. This study revisits the concept of CBMs in the context of cross-Strait tensions and suggests technical collaborations for human security at sea to tackle the fundamental difficulties in the initial stage of developing CBMs. A pragmatic framework for cross-Strait maritime CBMs, centered on a technical collaboration laboratory (TCL) model, is presented as a building block for security. Technologies could support cooperative measures, including cooperative detection of and collaborative response to human security threats at sea.
\end{abstract}




\section{Acronyms}

APEC

ARATS

ARF

ASEAN

CBM

CIB

CFE

CGA

CIMA

CIPA

CSBM

CSCAP

CSCE

DPP

EEZ

EPIRB

FTP

GMDSS

GPS

IIR Taiwan

ITMS

MBFR

NPA

PRC

RCC

SAR

SEF

SNL

SOLAS

TCL

VPN

VTS
Asia-Pacific Economic Cooperation

Association of Relations Across the Taiwan Strait

ASEAN Regional Forum

Association of Southeast Asian Nations

confidence building measure

Criminal Investigation Bureau

Conventional Armed Forces in Europe

Coast Guard Administration

China Institute for Marine Affairs

Criminal Investigation and Prevention Association

confidence and security building measure

Council for Security Cooperation in the Asia Pacific

Conference on Security and Cooperation in Europe

Democratic Progressive Party

Exclusive Economic Zone

Emergency Position Indication Radio Beacon

file transfer protocol

Global Maritime Distress and Safety Systems

Global Positioning System

Institute of International Relations at National Chengchi University

International Tracking and Monitoring System

Mutual and Balanced Force Reduction

National Police Administration

People's Republic of China

Rescue Coordination Centers

Search and Rescue

Strait Exchange Foundation

Sandia National Laboratories

Safety of Life at Sea

technical collaboration laboratory

virtual private network

Vessel Traffic Systems 


\section{Contents}

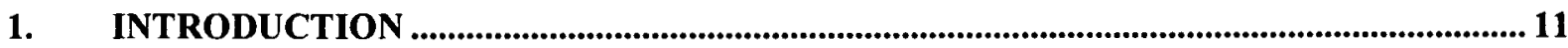

2. THE CONCEPT OF CBMS IN THE CONTEXT OF CROSS-STRAIT TENSIONS............ 11

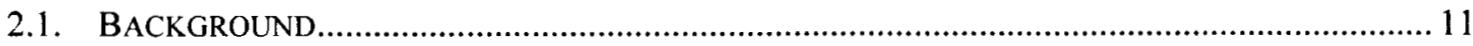

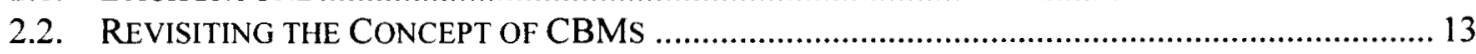

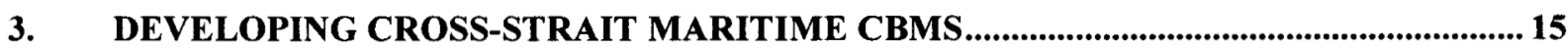

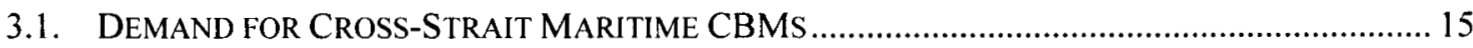

3.2. OPPORTUNITIES TO INITIATE CROSS-STRAIT MARITIME CBMS ........................................ 18

4. THE MECHANISM OF CROSS-STRAIT MARITIME CBMS.........................................20

4.1. TECHNICAL COLLABORATIONS FOR HUMAN SECURITY AT SEA ........................................ 20

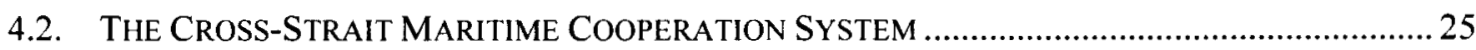

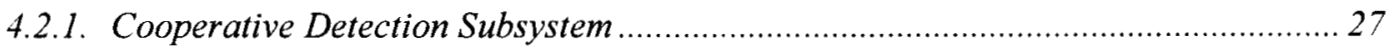

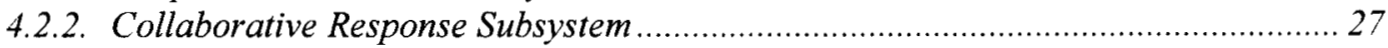

5. FINAL PERSPECTIVE: FROM CBMS TO CONFLICT PREVENTION............................ 29

\section{Figures}

Figure 1. THE CROSS-STRAIT MARITIME COOPERATION SYSTEM. 26

\section{Tables}

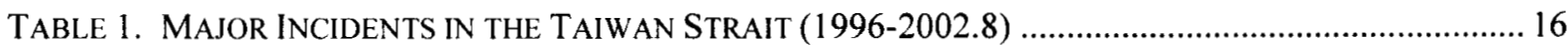

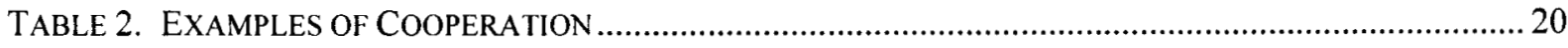

TABLE 3. TECHNICAL COLLABORATIONS FOR HUMAN SECURITY AT SEA ............................................. 21

TABLE 4. TECHNICAL AIDS FOR DETECTING HUMAN SECURITY THREATS AT SEA ................................22

TABLE 5. TECHNICAL AIDS FOR COLLABORATIVE RESPONSE TO HUMAN SECURITY AT SEA .................. 24

TABLE 6. POSSIBLE NON-GOVERNMENTAL PROXIES ...................................................................... 28 
Maritime Confidence Building Measures Across the Taiwan Strait:

Technical Collaboration for Human Security at Sea

This page intentionally left blank. 


\section{Maritime Confidence Building Measures Across the Taiwan Strait: Technical Collaboration for Human Security at Sea}

\section{Executive Summary}

Despite political hostility and diplomatic contention between the governments of Beijing and Taipei, people across the Taiwan Strait have maintained extensive economic and social exchanges since the early 1990s. The Strait Exchange Foundation (SEF) and the Association of Relations Across the Taiwan Strait (ARATS), two semi-official organizations, have represented Taiwan and mainland China, respectively, in negotiating arrangements for cross-Strait exchanges.

Due to the unique geographical and political background of the Taiwan Strait, there have always been both military security threats and human security problems in the Strait's maritime space. Combating human security threats at sea caused by either crimes at sea or natural disasters involves functional cooperation and operational coordination between jurisdictions. Although both sides implicitly agree that a "middle line" in the Taiwan Strait is the jurisdictional boundary, the cross-boundary movements and activities between people of both sides have been often beyond control. Criminal elements that commit acts of illegal trafficking, drug and gun smuggling, and armed robbery at sea often take advantage of such loopholes. The large amount of crime at sea not only endangers travelers passing through the Strait but also results in serious negative social and economic impacts on both sides and causes concerns of deteriorating security environments. In addition to crimes at sea, the high frequency of incidents at sea in the Taiwan Strait have delivered an alerting signal that any inappropriate handling of incidents could potentially escalate to armed fire.

However, there are potential areas for cooperation that could encourage human security at sea. Technical collaborations for human security at sea are suggested in this study to provide the basis of confidence building in the Taiwan Strait. Technical collaboration in security cooperation in general (and confidence building measures (CBMs) in particular) has both technical and strategic roles: it provides an objective source and the means of collecting, organizing, and analyzing information for jointly defined security goals. It also provides an important channel for improving the relationship and paves the way for future cooperation. Research and development of mutually acceptable technologies could become a cooperative effort in and of itself. Technical collaboration is particularly appropriate for cross-Strait CBMs because of its objectivity and low political sensitivity. Commitments to technical collaboration would reduce concerns of political risks, and thus become more likely at the initial stages of developing CBMs in tense relations. A cross-Strait maritime cooperation system could be composed of two subsystems:

- a limited cooperative detection system in which information exchanges and analyses in a specially established technical collaboration laboratory (TCL) provide credible and objective sources of data 
- a collaborative response system in which communication of immediate responses through informal channels could alleviate political distrust between Beijing and Taipei

The role of a TCL would be to reduce information biases due to either political distrust or technical failure, and facilitate efficient responses for promoting human security at sea. The concept of collaborative response stresses coordination of actions in response to incidents, rather than agreements on a joint operational procedure. The operational procedure need not be specified or designated in advance so that both sides would not be anxious about losing respective political capital before making commitments to collaborate.

The goal of this study was to suggest maritime CBMs that could be used as building blocks for maintaining peace and achieving security in the Taiwan Strait. It is an incremental approach to conflict prevention, rather than an institutional approach for crisis management. As long as the "one-China" issue remains the obstacle for normalizing cross-Strait relations, developing a cross-Strait maritime cooperation system could expand the scope and the content of cross-Strait constructive engagement. Such engagement on the one hand responds to the new security environments in which concerns of human security at sea have been highlighted, and, on the other hand, could transform the overall security policy environment from a tensionpreoccupied agenda to a coordination-driven one. 


\section{Maritime Confidence Building Measures Across the Taiwan Strait: Technical Collaboration for Human Security at Sea}

\section{Introduction}

The concept of confidence building measures (CBMs) has been in use for decades to reduce military tensions and political uncertainties among political adversaries or competing powers, particularly for tension reduction at regional flash points. Potential military confrontation across the Taiwan Strait has prompted attention from both academic scholars and policy researchers of Asia-Pacific security. Exploring new ways to reduce military tension and maintain peace across the Taiwan Strait has become an important security topic. Currently and in the future, increasing economic interdependence and social interactions may prompt both sides to establish joint efforts to ensure peace in the Taiwan Strait for the prosperity of both sides. Nevertheless, perceptions of state-centered and military-based requirements for CBMs have hampered both Beijing and Taipei from taking initiatives in the past. Progress may be made by considering an incremental approach to conflict prevention, rather than an institutional approach for crisis management. Moreover, informal modalities may be more feasible than state-centered concepts.

The objectives of this study are to revisit the concept of CBMs in the context of crossStrait tensions and explore the options for technical collaborations for human security at sea as the foundation of confidence building in the Taiwan Strait. In the first section, CBMs will be reconceptualized to tackle the increasing transnational/transboundary maritime security threats in the context of complex cross-Strait interdependence. In the second section, demands and opportunities of developing cross-Strait maritime CBMs will be assessed. In the third section, a pragmatic framework of maritime CBMs across the Taiwan Strait will be specified, including issues, mechanisms, and technical feasibilities. In the last section, the prospects of developing CBMs to achieve conflict prevention will be discussed.

\section{The Concept of CBMs in the Context of Cross-Strait Tensions}

\subsection{Background}

Despite political hostility and diplomatic contention between the governments of Beijing and Taipei, people across the Taiwan Strait have maintained extensive economic and social exchanges since the early 1990s. The Strait Exchange Foundation (SEF) and the Association of Relations Across the Taiwan Strait (ARATS), two semi-official establishments, represented Taiwan and mainland China to negotiate institutional arrangements of cross-Strait exchanges. However, the communication has been suspended since the former President Lee Teng-hui's visit to the United States in 1995.' The cross-Strait missile crisis in March 1996, ${ }^{2}$ the alleged

-1 Lee Teng-hui, who received his Ph.D. from Cornell University in 1968, delivered a speech at the Olin Lecture on June 9, 1995, as part of the university's alumni reunion weekend. In the speech, "Republic of China on 
State-to-state theory in July $1999,^{3}$ the shift of the Taiwan's Presidency to the Democratic Progressive Party (DPP) in 2000, ${ }^{4}$ and the incident of the 2001 Asia-Pacific Economic Cooperation (APEC) summit ${ }^{5}$ have gradually eroded the trust built by SEF and ARATS in the past.

In addition to the potential military confrontation and diplomatic suppression that have affected security for decades, transboundary non-traditional security issues (such as drug trafficking, illegal trade, smuggling, gun running, etc.) have emerged from the increasing economic and social interdependence across the Taiwan Strait and caused tremendous human security concerns for both sides. The suspension of cross-Strait functional communication due to political or diplomatic hostility has gradually transformed the security environment in the Taiwan Strait. The current phase of cross-Strait relations can be characterized as "cold peace." A strategic alliance with a third country or tactical responses to each other could make war less likely, in spite of the suspension of cross-Strait communication. However, the lack of strategic attention to human security concerns risks the long-term economic welfare and prosperity of people across the Taiwan Strait.

Human security is a newly developed international security agenda. The inquiry focuses on a broad range of threats (economic, food, health, environmental, community, and political) to individuals, ${ }^{6}$ rather than on a narrow range of external (military) threats to the territorial and political integrity of states, as do more traditional security concepts. Although the definitions of the concept vary due to different intellectual and professional backgrounds, the goal of human security is to secure the freedom from pervasive threats to people's rights, safety, or lives. ${ }^{7}$ The

Taiwan" was mentioned 16 times. Beijing thus condemned Lee's political intent of Taiwan's independence. Later, in July 1995, the Chinese fired six DF-15s from Fujian province to an East China Sea impact site 90 miles north of Taipei.

2 On the eve of Taiwan's first democratic presidential election, China launched four DF- $15 \mathrm{~s}$ into two ocean impact zones that would bracket the island. One zone was 47 miles west of the southern port of Kaohsiung and the other was just 30 miles east of the northern port of Keelung. The United States reacted by deploying a large force consisting of two carrier battle groups to the waters off Taiwan. Tensions of military confrontation escalated.

3 During a July 8, 1999, interview with Deutsche Welle radio, President Teng-hui Lee stated that relations between Taiwan and China were "special state-to-state" in nature. Beijing then cancelled the pre-scheduled trip of Wang Daohan, chairman of ARATS, to Taipei in October 1999.

In Taiwan's second democratic presidential election on March 18, 2000, Shui-bian Chen (an opposition candidate) was elected. Beijing hesitates to establish contacts with the pro-independence DPP government.

5 The 2001 APEC Shanghai Summit was once considered an opportunity to reduce the cross-Strait tension. However, Beijing failed to issue a visa to President Chen's proxy, Yuan-Chu Lee, because of his earlier governmental capacity as Vice President.

6 The term "human security" first came to prominence with the publication of the 1994 UNDP Human Development Report. It indicates seven elements of human security: economic security, food security, health security, environmental security, personal security, community security, and political security. The threats of each elements are poverty, hunger and famine, injury and disease, pollution and environmental degradation, violence and crime, integrity of cultures, and political repression.

7 Three major schools of thought on human security are (1) a rights-based approach in which normative legal frameworks at national, regional, and international levels are the solutions; (2) a humanitarian concept that highlights concerns about the safety of people and "freedom from fears"; and (3) a sustainable human development view that stresses issues of "freedom from wants." (For conceptual reviews of human security, see 
issue of human security at sea in this study particularly refers to crimes at sea and maritime search and rescue in the Taiwan Strait and the surrounding areas. Incidents of crimes at sea include illegal trafficking and smuggling conducted by fishing boats or vessels from both sides of the Taiwan Strait, and pirate activities in the Taiwan Strait. Maritime search and rescue issues are particularly focused on disaster relief and emergency rescue.

The concept of CBMs implemented in Europe ${ }^{8}$ and recently in the Asia Pacific ${ }^{9}$ could have provided more room for cooperation between Beijing and Taipei to cope with human security issues across the Taiwan Strait. Nevertheless, the myth of a state-centered and militaryoriented CBMs agenda has hampered both Beijing and Taipei in taking initiatives in the past. On the one side, Beijing has reiterated that creating CBMs is a concept applicable only among states. The controversies of the "one-China" issue ${ }^{10}$ have frozen the ability to conceptualize CBMs in cross-Strait relations. On the other side, considering the sensitivities and dilemma of military transparency for the physically weak party in the asymmetrical relations, Taipei has been very cautious about a CBM approach.

\subsection{Revisiting the Concept of CBMs}

The experience of applying the concept of CBMs in the Asia-Pacific security agenda has been widely discussed. 1 " Obviously, importing any specific security concept without

Fen Hampson (2002), "The Many Meanings of Human Security," in his Madness in the Multitude: Human Security and World Disorder (Oxford University Press), pp. 1-37; and Sabina Alkire (2001), Conceptual Framework for the Commission on Human Security (http://www.humansecurity-chs.org/doc/index.html).

8

The term CBMs was first used in the mid-1950s in connection with United States and Soviet open skies and ground post control proposals at the United Nations. It was later adopted to refer to the modest, politically binding, largely voluntary provisions on exercise notification and observation in the 1975 Helsinki Final Act of the Conference on Security and Cooperation in Europe (CSCE). The term "confidence and security building measures" (CSBMs) was introduced at the 1981-1983 CSCE Review Conference in Madrid by neutral and nonaligned European nations to denote measures that were more "militarily significant, politically binding and verifiable" than earlier measures. Western delegations to the 1975-1986 Mutual and Balanced Force Reduction (MBFR) negotiations had proposed CSBM type initiatives as "associated measures" to promote verification of conventional force limitations. The 1989-1992 Conventional Armed Forces in Europe (CFE) talks resurrected these measures as "stabilizing measures" designed to enhance verification. (See M. Susan Pederson and Stanley Weeks (1995), "A Survey of Confidence and Security Building Measures" in Ralph Cossa (ed.), Asia Pacific Confidence and Security Building Measures (Washington DC: CSIS, 1995), pp. 99.

9 In Asia Pacific, the term "CBMs" has been used since the ASEAN Regional Forum (ARF) in Bangkok in July 1994.

10 Debates on "one China" issues have been the major obstacle for resuming talks between both sides of the Taiwan Strait. Beijing's interpretation of the "one China" principle is that Taiwan is an inalienable part of China. In his early days in the presidential office, President Chen was willing to discuss the "one China" issue with Beijing as long as Beijing did not confine the talks under the "one China" principle. In August 2002 , President Chen addressed the status of Taiwan and China as "one country on each side of the Taiwan Strait." It exacerbated cross-Strait political distrust.

11 For examples, see Ralph Cossa, ed. (1995), Asia Pacific Confidence and Security Building Measures (Washington, DC: CSIS, 1995); Ralph Cossa (1998), "Asia-Pacific Confidence-Building Measures for Regional Security" in Michael Krepon et. al (eds.), A Handbook of Confidence Building Measures for Regional Security ( $3^{\text {rd }}$ edition) (Washington, DC: The Henry L. Stimson Center), pp. 15-39; and Desmond Ball, "The Most Promising CSBMs for the Asia Pacific Region," paper prepared for an international conference on "The Asia-Pacific Region: Links 
considering the local environments will not lead to immediate success. Thus, the concept of CBMs should not be universally applied without contextual specifications. In the context of cross-Strait tensions, three elements of CBMs should be highlighted to tackle the fundamental difficulties in the initial stage of developing CBMs.

First, developing CBMs is a pragmatic approach to a security objective. Idealists take ultimate goals as a point of departure and aim at winning every move, while pragmatists care more about relative significance and choose the lesser of two losses. Although a unilateral, bilateral, or multilateral pragmatic desire for cooperation is essential to develop successful CBMs, the motivations behind the negotiation of initial steps need not be in concert as long as they are not implacably hostile. All that is required is for each party to see value in the particular steps chosen and for those steps not to intensify existing levels of hostility. It is not necessarily driven by political willingness, ideological accommodation, or other liberalist thoughts of functionalism.

Second, developing CBMs involves an incremental building-block process. The process is often more important than the product. Thus, the format is not necessarily tied to institutional settings, but stresses the ongoing efforts of interactions. Conflict and cooperation often co-exist despite political tensions. The transformation of security environments from a conflict-devastated situation to a cooperation-dominated relationship is an evolving process, not revolutionary magic. An initial negotiating strategy may need to put more emphasis on "agreement and implementation," rather than on the "importance of the content" of the measures. Even when the contents of agreements are trivial and basic, the cumulative effects can be significant.

Third, the design of mechanisms for CBMs stresses the achievable implementation agenda. The principle of cooperative security encourages dialogue and engagement among political adversaries. However, dialogue and engagement without defined purposes can be difficult to sustain. The continuing utility of CBMs actually stems from the achievable implementation agenda and the adaptability to a transformed security environment. Therefore, an issue-oriented and sector-specific agenda with clearly defined objectives and measurable progress will be more appropriate at the start.

In the context of cross-Strait tensions, the pragmatic desire of cooperation is rooted in the prevention of military confrontation in the Taiwan Strait by both military and non-military means. The pragmatic objective is to make the choice of using armed forces from either side less likely through CBMs. Cutting the net of any established cross-Strait CBMs will incur security costs. Thus, both sides will be tied to CBMs to be better off. The incremental buildingblock approach of CBMs accumulates trust piece by piece and is particularly important to the context of cross-Strait tensions because any ambiguity or misunderstanding can easily increase tension and reverse the trend of cooperation. The most critical part of developing cross-Strait CBMs is to design an achievable implementation agenda. The implementation must first include the consideration of a format that is politically acceptable to both Beijing and Taipei. Measures that overreach the political willingness of both sides can become sources of contention rather than accommodation.

Between Economic and Security Relations," organized by the Institute on Global Conflict and Cooperation, University of San Diego, May 13-15, 1993. 
It would not be in the interest of either side if the self-restraint of state-centered and military-based CBMs is imposed at the initial stage of cross-Strait confidence building. In fact, both sides share tremendous contextual advantages in developing CBMs. These include sharing cultural and religious affinities; strong and stable political infrastructures of both Beijing and Taipei to legitimize CBMs; and Beijing's economic catch-up for technical feasibility of CBMs. Such contextual advantages provide important potential for accommodation in negotiation, despite the ideological gap and other differences dividing the two sides.

In sum, a more constructive and pragmatic definition of CBMs in the context of crossStrait tensions will include both formal and informal measures, whether unilateral or bilateral, that address, present, or resolve uncertainties between Beijing and Taipei for the purpose of conflict avoidance as well as tension reduction. The scope of implementation can cover humanitarian, economic, cultural, or military matters.

\section{Developing Cross-Strait Maritime CBMs}

\subsection{Demand for Cross-Strait Maritime CBMs}

Due to the unique geographical and political background of the Taiwan Strait, there have always been both military security threats and human security loopholes in the Strait's maritime space. Combating human security threats at sea caused by either crimes at sea or natural disasters involves functional cooperation and operational coordination between jurisdictions. Although both sides implicitly agree a "middle line" in the Taiwan Strait to be the jurisdictional boundary, the cross-boundary movements and activities between people of both sides have often been beyond control. Criminal elements that commit acts of illegal trafficking, drug and gun smuggling, and armed robbery at sea often take advantage of such loopholes. The large amount of crime at sea not only endangers travelers passing through the Strait but also results in serious negative social and economic impacts on both sides and causes concerns of deteriorating security environments.

In addition to crime at sea, the high frequency of incidents at sea in the Taiwan Strait have delivered an alerting signal that any inappropriate handling of incidents would potentially raise mistrust and trigger armed fire across the Strait. From January 1990 to May 2000 there were 237 fishing disputes, including 127 related to collisions, labor disputes, and entangled nets between Taiwan and mainland China's fishing boats. Another 55 cases involved Taiwanese fishing boats allegedly robbed by pirates from mainland China. In the remaining 55 cases, Taiwanese fishing boats allegedly were inspected and harassed by the Mainland Coast Guard. From January 1995 to May 2000, the Coast Guard operating in Taiwan forced trespassing fishing vessels from its waters 18,241 times. $^{12}$ Table 1 lists major incidents in the Taiwan Strait.

12 Statistics quoted from "Cross-Strait Economic and Trade Relationship" by John C.C. Deng (Vice Chairman, Mainland Affairs Cbuncil), http://www.rocinfo.org/govt_position/891226.htm. 
Table 1. Major Incidents in the Taiwan Strait (1996 to August, 2002)

\begin{tabular}{|c|c|c|}
\hline $\begin{array}{c}\text { Date } \\
\text { (M/D/Y) }\end{array}$ & Description & Highlights \\
\hline $02 / 19 / 1996$ & $\begin{array}{l}\text { Chinese cargo vessel Gu Cheng sank in } \\
\text { the Taiwan Strait; } 30 \text { crewmen were } \\
\text { missing. }\end{array}$ & $\begin{array}{l}\text { Taiwanese officials sent army helicopters and } \\
\text { a marine police vessel to search. }\end{array}$ \\
\hline 11/16/1998 & $\begin{array}{l}\text { Cheung Son, a Hong Kong bulk carrier, } \\
\text { was attacked in the Taiwan Strait. The } \\
\text { crew of } 23 \text { was beaten to death and the } \\
\text { bodies were tied to weights and thrown } \\
\text { overboard. }\end{array}$ & $\begin{array}{l}\text { An intriguing aspect of the case was that the } \\
\text { boat used for the attack had previously been } \\
\text { used for legitimate border defense purposes } \\
\text { and the pirates were in the uniforms of border } \\
\text { police. In December } 1999 \text {, China sentenced } \\
\text { the } 12 \text { pirates of that attack to death. }\end{array}$ \\
\hline 07/31/1999 & $\begin{array}{l}\text { Taiwanese cargo freighter Shin Hwan and } \\
\text { its } 10 \mathrm{crew} \text { members were detained by } \\
\text { Chinese Coast Guard for alleged } \\
\text { smuggling in waters near Matsu. }\end{array}$ & $\begin{array}{l}\text { Shin Hwan was a private freighter hired by the } \\
\text { Ministry of National Defense to ship provisions } \\
\text { to military servicemen in Matsu. } \\
\text { The crew were returned on December } 2,1999 . \\
\text { The case was not solved for } 5 \text { months due to } \\
\text { lack of a communication channel. }\end{array}$ \\
\hline $11 / 10 / 1999$ & $\begin{array}{l}\text { Taiwanese fishing boat Hechen } 11 \text { was } \\
\text { attacked by three mainland fishing boats in } \\
\text { Taiwan's territorial waters. Crews were } \\
\text { abducted. }\end{array}$ & $\begin{array}{l}\text { Taiwan's Coast Guard attempted a rescue but } \\
\text { did not find the boat. }\end{array}$ \\
\hline $02 / 28 / 2000$ & $\begin{array}{l}\text { The bulk carrier Hualien No. } 1 \text { with a cargo } \\
\text { of } 5300 \text { tonnes of gravel vanished during } \\
\text { the trip from Hualien to Tamsui; } 21 \text { crew } \\
\text { members have vanished. }\end{array}$ & $\begin{array}{l}\text { The case was not resolved due to lack of } \\
\text { coordination among governmental agencies } \\
\text { (Ministry of Transportation and } \\
\text { Communication, Coast Guard Administration). } \\
\text { The disappearance of the military vehicle } \\
\text { Hualien No. } 1 \text { has led to speculation that it was } \\
\text { held by the Chinese. }\end{array}$ \\
\hline $12 / 26 / 2000$ & $\begin{array}{l}\text { Coast Guard stations in Matsu and Kinmen } \\
\text { found unusual large-scale gatherings of } \\
\text { Chinese fishing boats. Matsu spotted a } \\
\text { Chinese fishing boat lurking just } 2 \mathrm{~km} \text { from } \\
\text { Kaoteng Island, part of the Taiwan- } \\
\text { controlled archipelago. The Coast Guard } \\
\text { fired } 16 \text { rounds of ammunition into the air } \\
\text { as a warning. Six crew members aboard } \\
\text { were arrested on the spot and the ship } \\
\text { sank into the sea. }\end{array}$ & $\begin{array}{l}\text { The incident happened right before the } \\
\text { opening of three mini-links. }\end{array}$ \\
\hline $04 / 28 / 2001$ & $\begin{array}{l}\text { The cargo ship Guangyuan Lun, registered } \\
\text { in Belize, with } 23 \text { Chinese crewmen, was } \\
\text { caught in Typhoon Chebi. }\end{array}$ & $\begin{array}{l}\text { The rescue effort was organized mainly from } \\
\text { the Taiwan-based rescue organization. The } \\
\text { Red Cross Society and the Rescue and } \\
\text { Salvage Centre of the Chinese mainland have } \\
\text { extended their thanks. }\end{array}$ \\
\hline
\end{tabular}




\begin{tabular}{|c|c|c|}
\hline $\begin{array}{l}\text { Date } \\
(\mathrm{M} / \mathrm{D} / \mathrm{Y})\end{array}$ & Description & Highlights \\
\hline \multirow[t]{3}{*}{$05 / 16 / 2001$} & $\begin{array}{l}\text { The Kaohsiug-registered Tsaifu No. } 1 \text { was } \\
\text { intercepted by a Chinese Customs cutter } \\
60 \mathrm{~km} \text { northeast of Pengchia Islet on } \\
\text { suspicion of having illegally sold diesel oil } \\
\text { to Chinese fishing boats. }\end{array}$ & $\begin{array}{l}\text { People's Republic of China (PRC) armed navy } \\
\text { (PRC anti-smuggling law enforcement officials) } \\
\text { boarded the vessel for inspection. Two Taiwan } \\
\text { Coast Guard ships and a Knox-class frigate } \\
\text { negotiated with PRC. }\end{array}$ \\
\hline & $\begin{array}{l}\text { It was released after on-the-spot } \\
\text { negotiation between the two sides. }\end{array}$ & $\begin{array}{l}\text { The spot is within Taiwan's } 200 \text {-nautical-mile } \\
(370-\mathrm{km}) \text { economic zone. }\end{array}$ \\
\hline & & $\begin{array}{l}\text { Highlighted the need for a mechanism to } \\
\text { enable a joint crackdown on crime at sea. }\end{array}$ \\
\hline $06 / 23 / 2001$ & $\begin{array}{l}\text { The Chinese sand carrier Guangyuan sank } \\
\text { during Typhoon Chebi near Tainan's } \\
\text { Anping. Taiwan authorities found } 13 \\
\text { bodies from the incident. }\end{array}$ & $\begin{array}{l}\text { Through SEF and ARATS communication, a } \\
\text { case of cross-Strait humanitarian rescue was } \\
\text { accomplished. }\end{array}$ \\
\hline $09 / 14 / 2001$ & $\begin{array}{l}\text { Two maritime officers of the Pehghu Coast } \\
\text { Guard Squadron were attacked by a } \\
\text { Chinese fishing boat that had sneaked into } \\
\text { Taiwan territory and conducted illegal trade } \\
\text { with the locals. Coast Guard personnel } \\
\text { were beaten and thrown into the sea. }\end{array}$ & Penghu police came to the rescue. \\
\hline $05 / 02 / 2002$ & $\begin{array}{l}\text { A tanker (the Front Tabago) carrying } \\
249,000 \text { tonnes of crude oil was originally } \\
\text { headed for Wakayama, Japan, but lost } \\
\text { power near Japan. Japan denied the ship } \\
\text { permission to enter its waters. It tried to } \\
\text { seek permission to enter Kaohsiung Port to } \\
\text { unload its oil and launch repairs but was } \\
\text { denied by the Ministry of Transportation } \\
\text { and Communications in Taiwan. On } \\
\text { May } 7 \text {, the tanker was towed to the Taiwan } \\
\text { Bank in the Taiwan Strait, } 260 \mathrm{~km} \text { from } \\
\text { Kaohsiung and } 148 \mathrm{~km} \text { from the coast of } \\
\text { China. }\end{array}$ & $\begin{array}{l}\text { The Ministry of Foreign Affairs urged China } \\
\text { and neighboring countries to cooperate and } \\
\text { fend off potential environmental disasters. The } \\
\text { Taiwan Bank is in the overlapping Exclusive } \\
\text { Economic Zone (EEZ) of Taiwan and China. } \\
\text { The Mainland Affairs Council, Taiwan, notified } \\
\text { China about the situation. }\end{array}$ \\
\hline $05 / 03 / 2002$ & $\begin{array}{l}\text { A Taiwanese skipper and a member of his } \\
\text { crew have been detained by Chinese } \\
\text { authorities in Pingtan, Fujian Province after } \\
\text { three Chinese illegal immigrants were } \\
\text { found dead on their fishing boat. The } \\
\text { fishing boat tried to smuggle } 11 \text { illegal } \\
\text { Chinese immigrants into Taiwan. }\end{array}$ & The SEF contacted the ARATS. \\
\hline $05 / 06 / 2002$ & $\begin{array}{l}\text { A Keelung-registered boat, Fusheng No. } 3, \\
\text { was discovered ablaze } 55.5 \mathrm{~km} \text { off } \\
\text { Pengchia Islet. The bodies of two } \\
\text { crewmen were found in the ocean by a } \\
\text { Chinese fishing vessel. }\end{array}$ & $\begin{array}{l}\text { The Keelung district Prosecutors' Office } \\
\text { arrested } 8 \text { suspects in connection with the } \\
\text { murders on June } 17,2002 \text {. The murders were } \\
\text { triggered by a disagreement between drug } \\
\text { dealers on the two sides of the Taiwan Strait. }\end{array}$ \\
\hline $08 / 07 / 2002$ & $\begin{array}{l}\text { A mainland Chinese gravel ship Haida, } \\
\text { registered under the flag of Belize, carrying } \\
2,700 \text { tons of river sand and other } \\
\text { commodities from Zhangzhou of Fujian, } \\
\text { lost power due to tropical storm Kammuri. }\end{array}$ & $\begin{array}{l}\text { Rescuers from Taiwan battled high waves to } \\
\text { evacuate } 14 \text { men from the ship. }\end{array}$ \\
\hline
\end{tabular}


The most recent incident that called for developing cross-Strait maritime safety and security cooperation is the incident of Tsaifu No.1. On May 16, 2001, the Kaohsiung-registered Tsaifu No. $l$ was intercepted and held by a Chinese anti-smuggling vessel about $60 \mathrm{~km}$ northeast of Pengchia Islet in the overlapping claimed EEZ of both Taiwan and China. The Tsaifu was suspected of illegally selling diesel oil to two Chinese fishing boats. The Chinese patrol allegedly crossed a hypothetical median line in the Taiwan Strait to arrest the vessel. China's armed anti-smuggling law enforcement officials boarded the vessel for inspection. Later, two Taiwan Coast Guard ships and a Knox-class frigate arrived to negotiate with China's officials. Although the vessel was released after on-the-spot negotiation, the boarding of China's officials caused considerable concern over whether China intends to reinforce its authority in the Taiwan Strait unilaterally. The incident could have led to fire exchanges or political recriminations if negotiation failed.

\subsection{Opportunities to Initiate Cross-Strait Maritime CBMs}

The idea of a cooperative approach to the management of safety and security in the Taiwan Strait has been much discussed over the years by SEF and ARATS. In the Kimen Agreement signed by the respective Red Cross societies on September 12, 1990, both sides agreed on crime fighting issues and repatriation of illegal immigrants. The SEF-ARATS joint agreement, effective in 1993, also identified issues related to joint combat of maritime crime and robbery and mutual assistance on judicial branches. It is hoped that through consultation on these issues, a formal channel for joint crime control can be established. However, the institutionalized solutions to crime at sea have been suspended since the former President Lee Teng-hui's visit to Cornell in mid-1995. In October 1998, the Koo-Wang Talk ${ }^{13}$ reached the agreement to provide more assistance on individual cases of cross-Strait civil distress, but the further implementation has not been realized due to the political stalemate.

Since then, apart from everyday verification of notarized documents, there has been no response with respect to the exchange of other intelligence of transboundary crimes, which has meant that effective crime fighting has been impossible. Recently, efforts were resumed at the non-governmental Track II level. Academic and research communities from both sides of the Taiwan Strait organized seminars and dialogues in which public security officers were able to attend without provoking political controversies. A seminar on "Cross-Strait Cooperation for Combating Crime" was held in May 1998 in Taipei. Two Shanghai public security officers and several scholars and experts from mainland China attended the seminar. On June 20, 2001, another cross-Strait academic exchange was held in Taipei. The Central Police University in Taiwan and the Chinese Police Society in mainland China co-organized the conference. The format of engagements moved from individual invitation toward more institutional coordination.

Recently, engagements have upgraded to the official level but with private capacities. In July 2001, 15 mainland Chinese incumbent and retired senior public security officers made a

${ }^{13}$ Chen-fu Koo is the chairperson of the Straits Exchange Foundation (SEF). Daohan Wang is the chairperson of the Association for Relations Across the Taiwan Strait (ARATS). The first Koo-Wang Talk was held in Singapore in April 1993 to lay a framework for regular SEF-ARATS dialogue. During October 14 to 16, 1998, the second Koo-Wang Talk was held. 
low-profile visit to Taiwan. In December 2001, the Criminal Investigation and Prevention Association (CIPA) organized a trip to China. The delegations included $\mathrm{Yu}$-jun Lu, the Chairman of CIPA, and Ching-sung Cheng, Director of the Criminal Investigation Bureau under the National Police Administration. This was the first time that senior Taiwan police officers visited the People's Republic of China (PRC) to promote bilateral cooperation in cracking down on crime. ${ }^{14}$ Although fighting crime involves the exercise of public authority and government policy, the law-enforcement agencies on both sides agreed that crime is a common enemy and keeping order is a common duty of all law-enforcement officers. A viable communication mechanism to exchange information about criminal activities under the principles of reciprocity, safety, and dignity would be of common interest to both sides. In January 2002, criminal-investigation authorities on both sides of the Taiwan Strait agreed tentatively to install a hot line to exchange information on crime.

In terms of search and rescue operations, recent developments have indicated mutual understanding and chances for future cooperation. The first joint sea rescue mission occurred in March 2001, when a Cambodian-registered cargo ship sank in the Taiwan Strait while carrying logs from Malaysia to South Korea. In this case, Taiwan authorities requested assistance from mainland China. A rescue ship was sent in response. One month later, the Guangyuan Lun, registered in Belize, with 23 Chinese crewmen, sank during Typhoon Chebi near Tainan's Anping in April 2001. Through SEF and ARATS communication, a cross-Strait humanitarian rescue mainly organized from the Taiwan-based rescue organization was accomplished. In May 2002, immediately after the China Airlines crash in the Taiwan Strait, ARATS and SEF arranged passage to the island for family members of nine mainland victims of the crash. The Maritime Search and Salvage Center in China sent two tugboats from the southeast port city of Xiamen to help with rescue efforts. Table 2 summarizes cooperative efforts between Taiwan and China.

14 The Central News Agency ("Taiwanese, Chinese Police to Discuss Human Smuggling, Drug Trafficking," Taipei, 12/10/01). In addition to exchanging views on halting cross-Strait human and firearm smuggling as well as drug trafficking, the two sides discussed cooperation in fighting economic crimes following their accession to the World Trade Organization. During its 12-day visit, the delegation met public security authorities in Shanghai and Guangdong and Fujian provinces as well as the PRC Police Society. The delegation visited the PRC's Ministry of Public Security and the Public Security Bureau under the Beijing City Government. 
Table 2. Examples of Cooperation

\begin{tabular}{|c|l|l|}
\hline $\begin{array}{c}\text { Date } \\
(M / D / Y)\end{array}$ & \multicolumn{1}{|c|}{ Description } & \multicolumn{1}{|c|}{ Highlights } \\
\hline $3 / 10 / 2001$ & $\begin{array}{l}\text { The Cambodian-registered cargo ship Pamela } \\
\text { Dream sank in the Taiwan Strait (between Fuzhou } \\
\text { and Matsu) on March 8 while carrying logs from } \\
\text { Malaysia to South Korea. Taiwan's National } \\
\text { Search and Rescue Center asked for help from } \\
\text { China. China sent a rescue ship in response. }\end{array}$ & $\begin{array}{l}\text { It was the first joint sea rescue between } \\
\text { Taiwan and China. }\end{array}$ \\
\hline $12 / 10 / 2001$ & $\begin{array}{l}\text { The Criminal Investigation and Prevention } \\
\text { Association (CIPA) organized a trip to China. The } \\
\text { delegates included Lu Yu-jun, the Chairman of } \\
\text { ClPA, and Cheng Ching-sung, Director of the } \\
\text { Criminal Investigation Bureau (ClB) under the } \\
\text { National Police Administration (NPA). }\end{array}$ & $\begin{array}{l}\text { It was first time that senior Taiwan police } \\
\text { officers visited China to promote bilateral } \\
\text { cooperation in cracking down on crime. } \\
\text { Counterparts in China will be public security } \\
\text { authorities in Shanghai, Guangdong, Fujian, } \\
\text { and the Chinese Police Society. }\end{array}$ \\
\hline
\end{tabular}

\section{The Mechanism of Cross-Strait Maritime CBMs}

The objectives at this stage are to establish new patterns of interaction that would become perceived as beneficial to both sides, and to make these patterns harder to reverse when perturbations occur. In this section, concrete ideas for designing cross-Strait maritime CBMs are suggested. Three particular concerns are critical in this regard. First, the format must be politically acceptable to both Beijing and Taipei. Due to the sensitivity of the issues, the near-term goal is to consume the least political capital in each side, but at the same time to generate the most added value from cooperation. Second, the substance must have a desirable security value. If either side of the Taiwan Strait loses security value while committing to cooperation, the content of cooperation will not be pursued. Third, the implementation must be technically feasible. The idea can be novel but the feasibility must be perceivable. However, the intent here is not to provide a comprehensive list for resolving the core cross-Strait issue at one time, but to tackle the very fundamental difficulties in the initiating stage by opening possible technical collaborations between Beijing and Taipei.

\subsection{Technical Collaborations for Human Security at Sea}

Technical collaborations for human security at sea are suggested in this study to build the basis of confidence building in the Taiwan Strait. Technical collaboration in security cooperation in general (and CBMs in particular) has both technical and strategic roles. On the one hand, it provides an objective source and the means of collecting, organizing, and analyzing information for jointly defined security targets. On the other hand, it provides an important channel for improving the relationship and paves the way for future cooperation. The research and development of mutually acceptable forms of technologies could become a cooperative effort in and of itself. Technical collaboration is particularly encouraged in the cross-Strait CBMs because of its objectivity and low political sensitivity. Commitments to technical collaboration would hardly cause concerns of political risks, and thus become more likely at the initial stage of developing CBMs in hostile relations. 
In terms of substance of cooperation, human security at sea focusing on crimes at sea and maritime search and rescue in the Taiwan Strait and the surrounding areas would generate great security value for both sides. The people-centered security objectives pursue long-term economic welfare and prosperity of people across the Taiwan Strait.

In terms of technical feasibility, technical collaboration for human security at sea should be composed of two parts: cooperative monitoring for threat detection (including both crimes at sea and emergency detection) and collaborative response to resolve the incidents and prevent incidents from escalating to conflicts. The technology of the cooperative monitoring has been applied to the implementation of regional security agreements as well as global non-proliferation treaties. $^{15}$ It provides a method of information sharing, and facilitates transparency through verification effectiveness. The concept could be applied to the detection of human security threats at sea. In relation to a collaborative response, the technological infrastructures used for crisis management and crisis prevention in other cases ${ }^{16}$ could be modified to facilitate communications and promptly resolve issues of human security at sea.

Table 3 highlights domains of technical collaborations for human security at sea. Technical points of departure for crimes detection as well as emergency search and rescue could include readily available and globally accepted technologies that supply information regarding vessel identity, location, navigational course, and high-value cargo integrity. It does not require any immediate collaborative detection regime, but rather enables independent information exchange for the detection of maritime problems. Following the technical detection, communication to coordinate the response proves vital.

Table 3. Technical Collaborations for Human Security at Sea

\begin{tabular}{|l|l|l|}
\hline \multirow{2}{*}{ Issues and Scope } & \multicolumn{2}{|c|}{ Domains for Technical Collaborations } \\
\cline { 2 - 3 } & \multicolumn{1}{|c|}{ Cooperative Detection } & \multicolumn{1}{c|}{ Collaborative Response } \\
\hline Crimes at Sea & $\begin{array}{l}\text { Vessel Tracking and Sensor } \\
\text { Monitoring }\end{array}$ & $\begin{array}{l}\text { Communication Establishment } \\
\text { and Response Coordination }\end{array}$ \\
\hline Maritime Search and Rescue & $\begin{array}{l}\text { Emergency Location and } \\
\text { Sensor Monitoring }\end{array}$ & \\
\hline
\end{tabular}

Among other technologies, satellite communications have revolutionized the shipping industry, increasing ship-to-shore and ship-to-ship interaction significantly. Global Positioning System (GPS) data, in conjunction with other systems, currently provide a wealth of location knowledge with near-real-time accuracy. Integrated systems involving the use of GPS location,

15 See Kent L. Biringer (1997), Cooperative Monitoring: a Framework for Issues Analysis and the Role of Technology, Sandia National Laboratories, USA; Moodie, Michael (2000), Cooperative Security: Implications for National Security and International Relations, Cooperative Monitoring Center Occasional Paper No. 14 (Albuquerque, NM: Sandia National Laboratories); and John Olson and Charles D. Harmon (2001), "Technology Development for Nuclear Transparency Application," paper prepared for the Third Annual JNC International Forum on the Peaceful Use of Nuclear Energy, Tokyo, Japan, February 21-22, 2001.

16 For the role of technology in conflict prevention, see Arian Pregenzer (1995), Crisis Prevention Centers as Confidence Building Measures: Suggestions for Northeast Asia, Sandia National Laboratories, USA. 
as well as satellite communication and tracking capabilities, are especially useful for possible maritime CBMs in general and detection of human security threat at sea in particular. Table 4 lists options for relaying vessel position and status to an outside source. A full analysis of available technologies must ultimately rely upon the specific cooperative activity explored. For illustration, this section will outline one technical system for both crimes at sea and emergency detection, as well as suggest a possible opportunity for cross-Strait information exchange.

Table 4. Technical Aids for Detecting Human Security Threats at Sea

\begin{tabular}{|c|c|c|}
\hline $\begin{array}{c}\text { Cooperative } \\
\text { Activity }\end{array}$ & Applicable Technology & Features \\
\hline \multirow[t]{4}{*}{$\begin{array}{l}\text { Maritime } \\
\text { Search and } \\
\text { Rescue (SAR) }\end{array}$} & $\begin{array}{l}\text { Traditional Radio/NHF } \\
\text { communication, Distress } \\
\text { Channel } 16\end{array}$ & $\begin{array}{l}\text { VHF distress transmission dependent upon receiver } \\
\text { tuned to appropriate channel and within radio range. }\end{array}$ \\
\hline & $\begin{array}{l}\text { Emergency Position- } \\
\text { Indicating Radio Beacon } \\
\text { (EPIRB) } 121.5 \mathrm{MHz}\end{array}$ & $\begin{array}{l}\text { Homing beacon deploys under } 3 \text { to } 15 \text { feet of water. } \\
\text { Signal is transmitted to COSPAS/SARSAT polar orbiting } \\
\text { earth satellite and relayed to land user terminal in } \\
\text { satellite view. Delay times from } 15 \text { minutes to } 4 \text { hours. } \\
\text { Approximate 9-mile margin of error. }\end{array}$ \\
\hline & EPIRB $406 \mathrm{MHz}$ & $\begin{array}{l}\text { Advanced EPIRB. Approximately 2.5-mile margin of } \\
\text { error. Additional 121.5-MHz frequency for local SAR. }\end{array}$ \\
\hline & INMARSAT-E GBIRP & $\begin{array}{l}\text { 1.6-GHz beacon with internal GPS locator is able to } \\
\text { transmit location to INMARSAT geostationary satellite. } \\
\text { Provides } 2 \text { - to } 5 \text {-minute data relay time and location } \\
\text { accuracy within } 200 \text { meters. }\end{array}$ \\
\hline \multirow[t]{3}{*}{$\begin{array}{l}\text { Vessel Tracking } \\
\text { and Sensor } \\
\text { Monitoring }\end{array}$} & $\begin{array}{l}\text { Vessel Traffic Systems } \\
\text { (VTS) }\end{array}$ & $\begin{array}{l}\text { Port equipment provides near-real-time vessel location } \\
\text { data and navigational message capacity for Port } \\
\text { Authorities. }\end{array}$ \\
\hline & ShipLOC & $\begin{array}{l}\text { Polar orbit satellites transmit delayed ( } 20 \text { min. to } 2 \text { hours) } \\
\text { location data to ship owners, with access to confidential } \\
\text { tracking website. If vessel is steered off course (or if } \\
\text { vessel indicates an alarm), owners notify the International } \\
\text { Maritime Bureau's Piracy Reporting Centre, which can } \\
\text { then notify proper law enforcement authorities throughout } \\
\text { Asia and respond to possible attack. }\end{array}$ \\
\hline & $\begin{array}{l}\text { International Tracking and } \\
\text { Monitoring System (ITMS) }\end{array}$ & $\begin{array}{l}\text { On-board sensors relay real-time, authenticated, } \\
\text { encrypted data regarding the status and integrity of ship } \\
\text { containers or alarms to main data station on board. This } \\
\text { information, coupled with GPS location, is transmitted via } \\
\text { INMARSAT geostationary satellites to an outside terminal } \\
\text { and superimposed upon navigational software in order to } \\
\text { provide transparency of vessel course, as well as } \\
\text { shipment integrity. }\end{array}$ \\
\hline
\end{tabular}


The International Tracking and Monitoring System (ITMS), developed and prototyped by Sandia National Laboratories (SNL), is one type of integrated system that illustrates the degree of vessel monitoring possible. ${ }^{17}$ ITMS integrates two fundamental aspects: a remote monitoring and data gathering system with a ground analysis system. The remote system is on board the vessel and employs intrusion detection devices, containment seals, environmental sensors, and a GPS device. Sensors gather information regarding the integrity and character of specific materials or containers en route. The sensor information is periodically collected, authenticated, encrypted, and then transmitted via satellite (such as INMARSAT or ORBCOMM) to a ground receiving station. This station then validates and interprets information for the user through graphical interfacing software. The ground station may also poll the remote system for updated information outside of normal transmission timeframes. ${ }^{18}$

This proposed system addresses recoverability by providing timely location and cargo status information so that an accurate incident description would be provided regarding if, where, when, and how a diversion or other incident took place. The ITMS could be applicable when transporting high value or hazardous cargo that could cause safety concerns or is under threat of theft or diversion. Systems using similar technologies could monitor cross-Strait cargo integrity and thus discourage illegal trafficking and smuggling, or hazardous material diversion. Basic vessel tracking could additionally encourage compatible vessel traffic schemes in port and deter crimes at sea.

In terms of maritime emergency detection, the United Nation's Safety of Life at Sea (SOLAS) Convention currently outlines mandatory levels for coastal and open sea Global Maritime Distress and Safety Systems (GMDSS). Distress signals currently range from mere radio transmissions on international emergency channel 16 to complex GPS transmitting beacons. Under the GMDSS, Emergency Position Indication Radio Beacons (EPIRBs) have become globally adopted. Several categories of EPIRBs currently exist. Mandated vessel requirements for EPIRBs depend upon vessel size, crew size, and navigational routes. In general, EPIRBs are mandated by government regulations to be carried on commercial fishing vessels, vessels over 300 gross tons, and vessels for hire that operate more than three nautical miles from shore and carry six or more passengers.

An EPIRB is essentially a homing device that can be manually or automatically deployed. A periodic signal is transmitted to a low-orbiting polar satellite. The cooperative COSPAS/ SARSAT emergency satellite systems developed by the United States, Russia, Canada, and France are tuned to receive distress signals worldwide. Once a satellite detects an EPIRB signal, it stores the registered user information and time-tags the signal to relay directly when passing over regional land Rescue Coordination Centers (RCC). Once an RCC receives signal information, it directly contacts the appropriate rescue authorities. The system is an international, humanitarian, satellite-based search and rescue system which operates all the time,

17 Although an updated version of ITMS is currently under development, elements of this system are commercially available at present.

18 The prototype for ITMS displayed this concept through a cooperative experiment transporting uranium ore from South Australia to Europe. Through this system, vessel location and cargo sensor information provided international, near-real-time vessel tracking, as well as authenticated, encrypted sensor data. 
automatically detects and locates emergency radio beacons globally by satellites, and alerts appropriate rescue authorities.

Nevertheless, most EPIRB emergency detection can often be delayed for hours. Additionally, the satellite transmissions often do not allow accurate positioning for local search and rescue officials who may face inclement weather or are far from the actual accident site. A rescue crew may be responsible for an area in which another authority may be closer or better equipped to respond, depending on the nature of the emergency. Collaborative search and rescue communication can alleviate current inadequacies. Sharing information regarding coastal response equipment and search and rescue operational responsibilities may prove a valuable and practical CBM for the Taiwan Strait.

Table 5 summarizes the technology available for improving human security at sea.

Table 5. Technical Aids for Collaborative Response to Human Security at Sea

\begin{tabular}{|c|c|c|}
\hline Infrastructure & Technical Options & Equipment \\
\hline \multirow[t]{6}{*}{ Communications } & \multirow{3}{*}{$\begin{array}{l}\text { Transmission link for simple data } \\
\text { streams }\end{array}$} & Voice links by telephone (hot line) \\
\hline & & Computer modem to telephone line \\
\hline & & Commercial satellite on dial-up basis \\
\hline & $\begin{array}{l}\text { Dedicated satellite links - High- } \\
\text { bandwidth, dedicated link with support } \\
\text { transmission of video images in } \\
\text { addition to voice }\end{array}$ & Typically $\$ 3000 /$ month for the satellite use \\
\hline & \multirow[t]{2}{*}{$\begin{array}{l}\text { Internet - Virtual Private Network } \\
\text { (VPN) }\end{array}$} & $\begin{array}{l}\text { *Inexpensive Internet infrastructure with full } \\
\text { encryption from end to end }\end{array}$ \\
\hline & & $\begin{array}{l}\text { *Privacy for } \$ 5000 \text { at each end, then a minor } \\
\text { charge per month for local service provider }\end{array}$ \\
\hline \multirow{9}{*}{$\begin{array}{l}\text { Supporting } \\
\text { Negotiations and } \\
\text { Consensus } \\
\text { Building }\end{array}$} & Transmission of documentation & Facsimile machines \\
\hline & & Encrypted email \\
\hline & & $\begin{array}{l}\text { Access-controlled File Transfer Protocol (FTP) } \\
\text { Web server for large data files }\end{array}$ \\
\hline & \multirow{5}{*}{$\begin{array}{l}\text { Discussion of issue by video } \\
\text { conference }\end{array}$} & Voice-activated, auto-zooming cameras \\
\hline & & Large display screen \\
\hline & & Document viewer \\
\hline & & Trained operators \\
\hline & & Compatible systems at both ends \\
\hline & Classrooms for education and training & \\
\hline
\end{tabular}

After security issues are properly detected, response elements become paramount. A trusted foundation for collaborative response requires frequently employed communication lines. Although the political hot line is a popular concept for high-level emergency or crisis management discussions, it seems to do little to instill long-term trust in communication systems between regions of tension. It is often argued that these emergency lines of communication are the first to break down in a crisis if not well established and used regularly. Alternatively, technical tools for facilitating communications in collaborative responses for human security at 
sea could consist of patrol hot lines, video conferencing technology, and virtual private network (VPN), as explained below.

Most cases of crimes at sea in the Taiwan Strait involve smuggling between fishing boats. Frequent patrols become critical to deter illegal trafficking or smuggling at sea. Nevertheless, without communication between patrol agents of both sides, any unilateral action could be misinterpreted as an intrusion of jurisdiction and escalated into a political incident. Thus, the establishment of patrol hot lines would enable prompt communications and prevent incidents at sea from becoming sources of political tensions.

Video conferencing technology has been widely used in business, schools, and other professional activities. It allows two or more people at different locations to conduct real-time visual connection and interaction. A videoconference system includes audio-visual equipment (such as voice-activated, auto-zooming cameras, and large display screen) as well as a means of transmitting information between sites. ${ }^{19}$ Both ends should be equipped with compatible systems. Video conferencing technology used in confidence building measures would be particularly useful for supporting collaboration between parties that are traditionally isolated from each other and unlikely to normalize their relations in the near future. In the context of cross-Strait CBMs, interactions via videoconferencing could be used as a means to avoid face-toface confrontation and provide both sides with more flexibility.

In terms of coordinating response to threats of human security at sea among parties with insufficient political trust, releasing any information or communication of joint efforts at an early stage could possibly cause public anxieties and lead to unwanted speculation. VPN establishes a secured channel within the Internet to provide privacy and integrity in sensitive exchanges. VPN patrons install compatible hardware or software to encrypt ${ }^{20}$ and authenticate ${ }^{21}$ their exchanges and protect them from "hackers." VPN is an inexpensive Internet infrastructure with full encryption from end to end. VPN can provide secure data links over high-bandwidth Internet links, while improving access and potentially reducing communication costs.

\subsection{The Cross-Strait Maritime Cooperation System}

Some technologies discussed in the last section are already in place and heavily used by vessels and ports worldwide; others are under extensive research and developments. However, regions of tension often fail to share either technological capacities or research information. More region-specific or issue-specific designs should be encouraged to tackle particular political difficulties between two sides of the Taiwan Strait. Due to the lack of official communication

19 A broadband satellite connection with studio-quality equipment produces an excellent full-motion video connection, but the equipment and transmission expense is huge. Recent advances in computer and telecommunications technologies have sparked an interest in compressed video systems, which transmit information via the Internet or telephone network, greatly reducing the cost of video conferencing.

20 Encryption converts data from a readable format to cipher text that only the intended recipient can decipher. Most VPNs include encryption algorithms such as 3DES, DES, RC5, Blowfish, CAST, or IDEA.

21 Authentication verifies that the data have not been altered, substituted, or removed. It does this by creating a unique signature based on the data. If the data were altered, re-authentication by the recipient would show mismatched signatures. VPN data authentication can use a number of algorithms including MD5 and SHA-1. 
between Beijing and Taipei, an immediate buildup of an extensive maritime cooperative regime or joint operations would be highly unlikely; yet any misunderstandings in their individual operations for combating crimes at sea or emergency rescue and search could possibly trigger political debates and escalate tensions. Therefore, a pragmatic objective of cross-Strait maritime cooperation would be to prevent any incident at sea from turning into a potential conflict.

Two critical elements include (1) assurance of information transparency between both partners and (2) communication of immediate responses to issues of human security at sea.

Technical collaborations suggested in the last section will play important roles in both elements. A cross-Strait maritime cooperation system with technological applications is suggested in this section. It is composed of two subsystems: a limited cooperative detection system in which information exchanges and analyses in an established technical collaboration laboratory (TCL) provide credible and objective sources of data to avoid factual debates due to political distrust, and a collaborative response system in which communication of immediate responses through established channels could alleviate political distrust between Beijing and Taipei. (See illustration in Figure 1.)

\section{Cross-Strait Maritime Cooperation System}

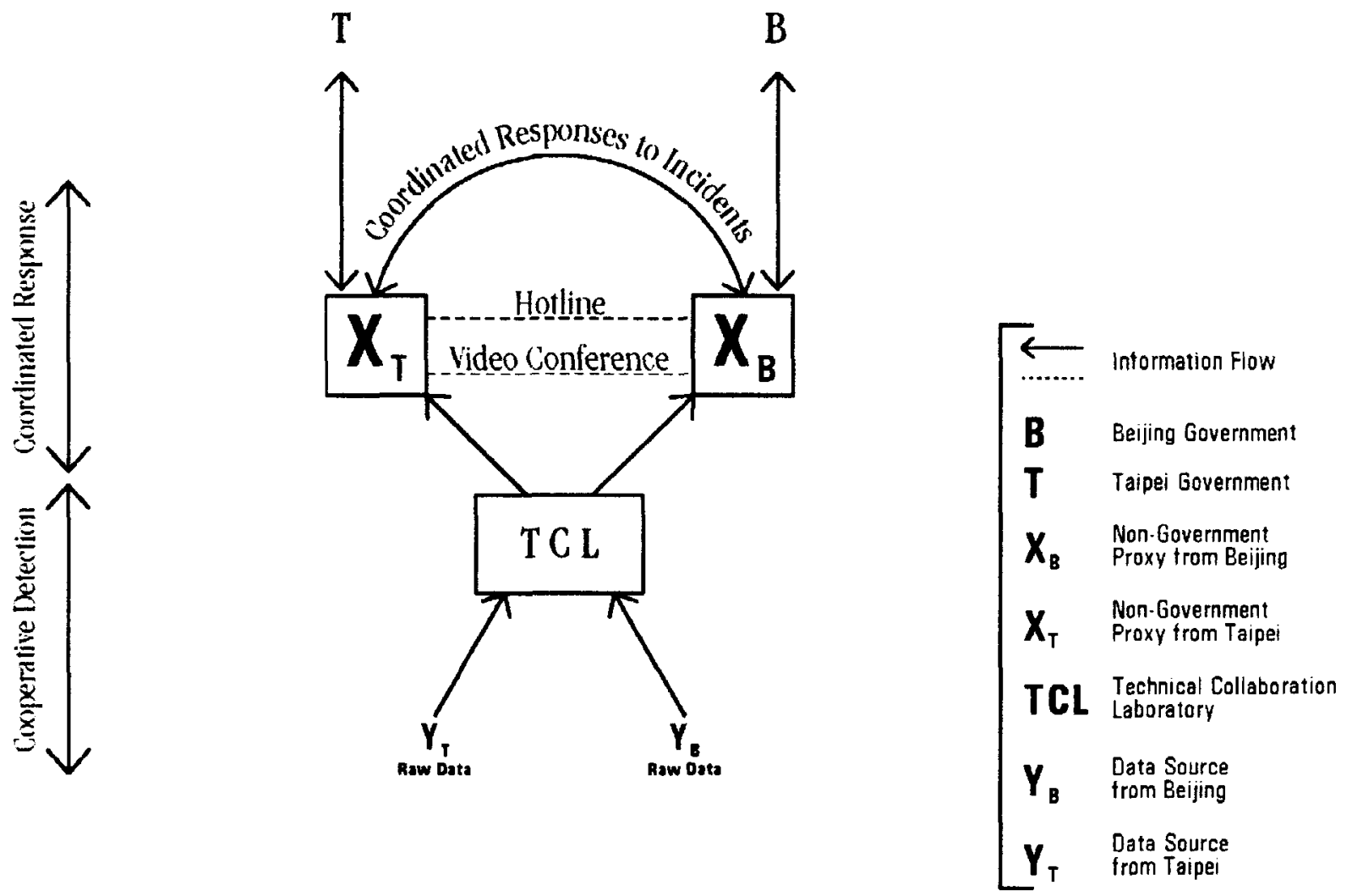

Figure 1. The Cross-Strait Maritime Cooperation System 


\subsubsection{Cooperative Detection Subsystem}

The major component of cross-Strait cooperative detection subsystem for human security at sea would be the establishment of a technical collaboration laboratory (TCL) in which scientists and technicians from both sides of the Taiwan Strait could be invited to work together under a framework of agreements. Cooperation among scientists and technicians would cost hardly any political capital; thus, it is the least politically sensitive and most feasible. The tasks of TCL would include four major dimensions.

First, TCL could be used to synchronize raw information collected from local agents. That is, instead of extensively sharing the equipment or hardware of information collection (i.e., a satellite system), data from Taipei $\left(\mathrm{Y}_{\mathrm{T}}\right)$ and data from Beijing $\left(\mathrm{Y}_{\mathrm{B}}\right)$ would be collected respectively by each side using their own means but further organized by the TCL.

Second, TCL would transmit agreed data and information to both the non-governmental proxy of Taipei $\left(\mathrm{X}_{\mathrm{T}}\right)$ and the non-governmental proxy of Beijing $\left(\mathrm{X}_{\mathrm{B}}\right)$ for their consideration of collaborative responses to incidents at sea.

Third, TCL could support technical requirements for the collaborative response subsystem, mainly communication technical support between $\mathrm{X}_{\mathrm{T}}$ and $\mathrm{X}_{\mathrm{B}}$, as needed.

Fourth, TCL would further explore options for an extensive cooperative monitoring system for human security at sea. In other words, TCL would be a research and development mechanism for a deeper and broader cross-Strait maritime cooperation system.

In sum, when an incident happens, technicians in TCL would immediately organize data and transmit the information to the collaborative response subsystem. The role of TCL would be to reduce information biases due to either political distrust or technical failure, and facilitate efficient responses for promoting human security at sea.

\subsubsection{Collaborative Response Subsystem}

The second subsystem in the cross-Strait maritime cooperation system is the collaborative response subsystem. The concept of collaborative response stresses coordination of actions in response to incidents, rather than agreements on a joint operational procedure. In other words, the operational procedure need not be specified or designated in advance so that both sides would not be anxious about losing respective political capital before making commitments to collaborate. A declaratory measure of confidence building, which states the good will of both sides to collaborate for human security at sea, would be a good start.

Communication technologies described in the previous section could be used in developing the cross-Strait maritime CBMs. However, the selection of agents to perform the communication is essential. Maritime issues have been managed by various agents on each side of the Taiwan Strait. Inter-agent integration could be a challenge to both Beijing and Taipei. Since cross-Strait governmental cooperation at this moment is highly unlikely, selecting non-governmental proxies to deliver the jurisdictional messages across the Taiwan Strait would be critical. 
The optimal candidates ought to have two attributes: internal networking capacity and external representation.

First, the agents must have strong internal networking capacity. It could be non-governmental organizations or institutions with sufficient knowledge of maritime issues in general and frequent contacts to officials of crimes at sea and SAR in particular. The proxies should have the channels to network among governmental agents and consult with various agents when responses to incidents at sea require inter-agent cooperation.

Second, the agents must have sufficient external representation. The proxies should have effective accesses to higher political authority in government. In addition to functional operation, the proxies should be able to represent political willingness and strategic concerns of the higher authorities in Beijing or Taipei. Thus, a certain degree of implicit or explicit consent on cooperation between the two sides has to be reached.

In addition to collaborations of responses through technological cooperation, constant dialogue between $X_{T}$ and $X_{B}$ should be encouraged to explore other common concerns and creative ideas of cross-Strait maritime security cooperation.

Agents of both sides suggested in Table 6 have ongoing contacts and communications. In Taiwan, CIPA was founded in 1992 by retired and current high-ranking police officers and legislators. The main purpose of CIPA is to combat crime committed by Taiwan's citizens abroad. The group also functions as a semi-official channel for Taiwan to establish links with external police authorities. On the mainland, the China Police Society is considered to be a front organization of the Department of Public Security and acts as an informal contact point with foreign counterparts of police studies associations, especially that of Taiwan and its police force. Both organizations have some contact through the exchange of visits and Track II activities. Nevertheless, the scope of their discussions has been broader crime issues, not necessarily with the focus of crime at sea. Thus, the function of preventing crime at sea from turning to political or military incidents might be limited.

Table 6. Possible Non-Governmental Proxies

\begin{tabular}{|l|l|l|}
\hline \multicolumn{1}{|c|}{ Area of Interest } & \multicolumn{1}{|c|}{ China } & \multicolumn{1}{c|}{ Taiwan } \\
\hline Crime at Sea & China Police Society & $\begin{array}{l}\text { Criminal Investigation and } \\
\text { Prevention Association }\end{array}$ \\
\hline Maritime SAR & $\begin{array}{l}\text { ARATS, Red Cross Society of } \\
\text { China }\end{array}$ & SEF, Red Cross Society of Taiwan \\
\hline Overall Maritime Security & CSCAP China & CSCAP Taiwan \\
\hline
\end{tabular}

In terms of SAR, the Maritime Safety Administration of PRC is responsible for maritime safety of navigation. The Maritime Rescue and Salvage Center of PRC is responsible for guiding and coordinating rescue and salvage operations in the coastal areas. Both have made combating and co-investigating cases of piracy and armed robbery an important component of their functions and duties to ensure the safety of navigation. In Taiwan, the National Search and 
Rescue Center under the Ministry of National Defense is responsible for coordinating overall SAR, while local Search and Rescue Associations are also essential in SAR. The Coast Guard Administration (CGA) has handled mainly coastal patrol and anti-smuggling efforts. In April 2002, the Executive Yuan announced plans to establish a Maritime Affairs Ministry in two years, in which CGA will take the leading role in the formation of the country's maritime policy. Currently, there is no formal arrangement between both sides of the Taiwan Strait regarding SAR. However, when it is needed, both sides offer assistance on ad hoc bases through Red Cross Societies or SEF and ARATS.

For overall maritime human security issues, the Council for Security Cooperation in the Asia Pacific (CSCAP), a regional Track II mechanism for multilateral security dialogue, has provided Taipei and Beijing with opportunities to exchange views of regional security concerns since 1996. ${ }^{22}$ Although "cross-Strait issues" are currently not on the agenda of CSCAP working groups, ${ }^{23}$ previous engagements in the working groups have built a constructive foundation for Taipei and Beijing to initiate possible cooperation for human security at sea. In Taipei, the Institute of International Relations at National Chengchi University (IIR Taiwan) coordinates Taiwan's participation in CSCAP activities. It has strong internal and external channels of networking policy and research communities with regard to regional security issues and crossStrait relations. In Beijing, the Secretariat of CSCAP China is located in the China Institute of International Studies under the Ministry of Foreign Affairs. The China Institute for Marine Affairs (CIMA) under the State Oceanic Administration has been coordinating China's participation in the CSCAP Maritime Cooperation Working Group. IIR Taiwan and CIMA China launched a bilateral cooperation forum in November $2001^{24}$ and have indicated good will and intentions of further engagements.

\section{Final Perspective: From CBMs to Conflict Prevention}

The goal of this study was to develop maritime CBMs as building blocks for maintaining peace and achieving security in the Taiwan Strait. It is an incremental approach to conflict prevention, rather than an institutional approach for crisis management. As long as the "oneChina" issue remains the obstacle for normalizing cross-Strait relations, developing a crossStrait maritime cooperation system would extensively expand the scope and the content of crossStrait constructive engagements. Such engagements on the one hand respond to the new security environments in which concerns of human security at sea have been highlighted, and, on the other hand, would transform the overall security policy environment from a tension-preoccupied security agenda to a coordination-driven one. Through transformation of policy environments, the security perceptions of policy-makers could be shifted from a tension-oriented to a cooperation-dominated mindset.

\footnotetext{
22 CSCAP was established in July 1993. China became a formal committee member in 1996. Scholars and security specialists from Taiwan are invited to participate in CSCAP working group meetings in their private capacities. The arrangements make CSCAP one of the rare venues where delegations from Taiwan and mainland China discuss security issues together.

23 Due to objections from China, cross-Strait security and political issues have not been formally on CSCAP agenda. However, international delegations often exchange views on cross-Strait issues informally.

24 The forum was held in November 2001 in Taipei. The discussion was mainly on South China Sea issues.
} 
The potential role of Technical Collaboration Laboratories (TCL) is to facilitate obtaining and sharing information relative to various maritime CBM agreements. In each domain of cross-Strait cooperation, including maritime, environmental, economic, military, etc., there might be both a cooperative monitoring subsystem to detect common human security threats and a collaborative response subsystem to prevent incidents from being potential conflicts. The technical collaboration for each domain needs to be developed to improve the security environment of a particular human security concern. Nevertheless, the functions and the operational principles would be similar to what we have elaborated in maritime CBMs. That is, in order to respond effectively to human security threats that both sides of the Taiwan Strait commonly face, joint efforts of problem monitoring and solving become inevitable.

The information flow from non-governmental proxies in each security domain to the central governments in Beijing and Taipei would constantly indicate the importance of cooperation for human security. The cross-Strait security environments and policy agenda would be shifted from tension-preoccupied to coordination-driven in nature. The transformation of security environments is an evolving process in which any single cooperation provides an incremental improvement. Thus, the value of developing CBMs through technical collaboration should not be underestimated as a low security priority. Instead, the strategic goal of cross-Strait conflict prevention should be clearly in mind while initiating multi-dimensional confidence building measures. 


\section{Selective Bibliography}

Alkire, Sabina (2001), Conceptual Framework for the Commission on Human Security (http://www.humansecurity.chs.org/doc/index/html).

Biringer, Kent (1997), Cooperative Monitoring: A Framework for Issues Analysis and the Role of Technology, Sandia National Laboratories, Albuquerque, NM, USA.

Cheon, Seongwhun (1999), Cooperatively Enhancing Military Transparency on the Korean Peninsula: A Comprehensive Approach, Cooperative Monitoring Center Occasional Paper No. 10, Sandia National Laboratories, Albuquerque, NM, USA.

Cossa, Ralph, ed. (1995), Asia Pacific Confidence and Security Building Measures (Washington DC: CSIS, 1995).

Cossa, Ralph A. (1998), "Asia-Pacific Confidence-Building Measures for Regional Security," in Michael Krepon, et al. (eds.), A Handbook of Confidence-Building Measures for Regional Security $3^{\text {rd }}$ Edition (The Henry L. Stimson Center Handbook No. 1).

Deng, John C.C. "Cross-Strait Economic and Trade Relationships," http://www/rocinfo.org/ govt position/891226.htm.

Durrani, Mahmud Ali (2001), Enhancing Security Through a Cooperative Border Monitoring Experiment: A Proposal for India and Pakistan, Cooperative Monitoring Center Occasional Paper No. 21, Sandia National Laboratories, Albuquerque, NM, USA.

Griffiths, David N. (2000), Maritime Aspects of Arms Control and Security Improvement in the Middle East, Institute on Global Conflict and Cooperation Policy Paper No. 56 (San Diego, CA: IGCC, University of California).

Hampson, Fen (2002), "The Many Meanings of Human Security," in his Madness in the Multitude: Human Security and World Disorder (Oxford University Press), pp. 1-37.

Kao, Cheng-sheng (2002), "Discussion of Cross-Strait Cooperation in Crime Fighting," Exchange No. 63, June 2002, pp. 30-32.

Krepon, Michael, Jenny S. Drezin, and Michael Newbill (eds.) (1999), Declaratory Diplomacy: Rhetorical Initiatives and Confidence Building, The Henry L. Stimson Center Report No. 27.

Moodie, Michael (2000), Cooperative Security: Implications for National Security and International Relations, Cooperative Monitoring Center Occasional Paper No. 14, Sandia National Laboratories, Albuquerque, NM, USA.

Nam, Man-Kwon, and Shin, Sung-Tack (1999), ENTNEA: A Concept for Enhancing Nuclear Transparency for Confidence Building in Northeast Asia, Cooperative Monitoring Center Occasional Paper No. 12, Sandia National Laboratories, Albuquerque, NM, USA. 
Olsen, John N., and Charles D. Harmon (2001), "Technology Development for Nuclear Transparency Application," paper prepared for the Third Annual JNC International Forum on the Peaceful Use of Nuclear Energy, Tokyo, Japan, February 21-22, 2001 (http://www.cmc.sandia.gov/Links/about/papers/jolsenTransApp/JNCpaper.htm).

Pederson, M. Susan, and Stanley Weeks (1995), "A Survey of Confidence and Security Building Measures," in Ralph Cossa (ed.), Asia Pacific Confidence and Security Building Measures (Washington, DC: CSIS, 1995), pp. 81-100.

Pregenzer, Arian L. (1995), Crisis Prevention Centers as Confidence Building Measures: Suggestions for Northeast Asia, SAND 94-1527 (Albuquerque, NM: Sandia National Laboratories).

Siddiqa-Agha, Ayesha (2000), Maritime Cooperation Between India and Pakistan: Building Confidence at Sea, Cooperative Monitoring Center Occasional Paper No. 18, Sandia National Laboratories, Albuquerque, NM, USA.

Sidhu, Waheguru Pal Singh, and Yuan, Jing-Dong (1999), Cooperative Monitoring for Confidence Building: A Case Study of the Sino-Indian Border Areas, Cooperative Monitoring Center Occasional Paper No. 13, Sandia National Laboratories, Albuquerque, NM, USA. 


\section{About the Author}

Chyungly Lee is an Associate Research Fellow at the Institute of International Relations, National Chengchi University in Taiwan. She received her Ph.D. from the University of Maryland, Department of Government and Politics, in 1995. Her international experiences include Visiting Scholarships through the Cooperative Monitoring Center, Sandia National Laboratories, USA, in spring 2002 and through the Center for International Relations, Liu Institute for Studies of Global Issues, University of British Columbia, in autumn 2002. She is an active participant in the Council for Security Cooperation in Asia Pacific (CSCAP) and has been coordinating Taiwan's participation in CSCAP-related activities since May 2000. Her recent publications and current research have focused on non-traditional security issues in the Asia Pacific, particularly on the perspectives of economic security and human security. 
Maritime Confidence Building Measures Across the Taiwan Strait:

Technical Collaboration for Human Security at Sea

\section{Distribution}

350 MS 1373 CMC Library, 5341

1 MS 9018 Central Tech Files, 8945-1

2 MS 0899 Technical Library, 9616

1 MS 0619 Review \& Approval Desk, 9612 